\title{
Research on Diversification Optimization of Investment Business of A State-owned Company in Corps-Based on BCG Matrix
}

\author{
Du Qin, Yu Xiaoling \\ College of Economic and Management, Tarim University, Alar, Xinjiang 843300
}

Key words: A Company, diversification strategy, BCG matrix method

\begin{abstract}
In recent years, due to the impact of many factors, China's real estate industry has been greatly affected. Real estate agencies have to adjust their own development strategies in order to seek further development in the future. A State-owned Company in Xinjiang Corps, hereinafter referred to as A Company, is also a construction company in the early stage, and there are some problems in the diversification of investment business. In this paper, the author uses the BCG matrix method to analyze the diversified investment strategy of A Company, and puts forward some suggestions for its strategic development. Here, the author also hopes that this research can provide references and suggestions for similar enterprises to implement a diversified investment strategy, so that enterprises can better avoid risks for further development to promote the fast and steady economic development in Xinjiang.
\end{abstract}

\section{Introduction}

A Company is a state-owned company in Xinjiang Corps, which was a construction engineering limited company in the early stage. In recent years, with the depression of the real estate industry, A Company has implemented the strategy of diversification investment and developed into a diversified enterprise with many subsidiaries. Its main investment directions include real estate, property, shopping mall, power installation, comprehensive detection, food, ecological environment technology, packaging and agricultural cooperatives. The main businesses involved are real estate development, vehicle testing, trade, and property, tourism, packaging, food, and development of characteristic agricultural products. After many years of development, A Company has become an influential large enterprise around the corps, which has made many contributions to the economic construction and social development of the corps.

\section{Theory of investment diversification strategy and BCG matrix method}

Investment diversification strategy is that enterprises have diversified investment directions, which are not limited to the original investment in architecture, but also can be the investment in other directions related to architecture and cross-industrial investment. The direction of investment is diversified, but the risks will be greater.

\subsection{BCG matrix method}

BCG matrix method (Boston matrix method), also known as BCG growth-share matrix, was proposed by the famous American consulting company The Boston Consulting Group (BCG). And it is the most common portfolio analysis method for business investment, and the method to analyze diversification strategy. According to the market growth rate and the relative market share, the strategic business units are divided into four categories. The first are question marks, which are businesses operating with a low market share in a high-growth market. The second are stars, which are units with a high market share in a fast-growing industry. The third is Cash cow which is the business with a high market share in a slow-growing industry. The fourth are dogs, which are units with low market share in a slow-growing industry. 


\section{Analysis of investment diversification strategy in A Company}

A Company is a building engineering company for a long time, which obtained favorable development due to the popular real estate industry several years ago. However, with the cooling of the real estate industry, A Company has gradually embarked on the strategic path of diversification of investment. In the early stage, the company only implemented the relevant investment diversification strategy while the investment was mainly in building materials, building decoration and other directions related to buildings. In the later stage, A Company has carried out non-related diversification strategy and developed business across many industries. These projects include trade, vehicle testing, tourism, packaging, agriculture, food and so on. In the implementation of the non-related diversification strategy, these projects, which have nothing to do with its original business, have scattered the limited resources of A Company instead of helping the performance of the company. What's more, the complexity and confusion of management have led to some losses in the business and limited the overall development of A Company.

From the strategic portfolio of A Company, according to the market growth rate and the relative market share, the strategic business units are divided into four categories. Cash cows are business units with a high market share in a slow-growing industry, such as real estate development, property, power installation and vehicle inspection. There are no star businesses. Question marks are business units operating with a low market share in a high-growth market, such as food and ecological technology. Dogs are business units with low market share in a slow-growing industry, such as trade, packaging and tourism.

For stars, the current strategic business units of A Company have no one with a high market growth rate and a high relative market share, so it is temporarily vacant in the position of such business unit. The company should adjust its original strategic choice according to the implementation of the company's investment diversification strategy, and then make accurate strategic planning, and strive to make certain business units into star business. The star business means to be in the leading position in the whole industry, so there is profit maximization, which is the goal of all enterprise strategy. For cash cows, A Company's real estate development, property, power installation, vehicle inspection and other business units belong to cash cows, which are the traditional business of the company in large scale of production and operation, long operation time, large market share, high profit margins, low debt ratio and great advantages. Moreover, these businesses have sustained and stable operation, high profit margin and low risks, so they are the most important source of funding for enterprises. Therefore, for the business units of cash cows in A Company, the company doesn't have to invest a lot in expanding the market, but should continue to provide sufficient cash to meet the needs of the implementation of the corporate diversification strategy, and support other business units in need of cash. It is recommended that the company maintain the existing market share and maintain the strategy of maintaining the business unit status, so as to obtain more funds to focus on the development of other business units. In short, continued expansion of investment is undesirable, and it is difficult for the business unit to become star business. For question marks, food and ecological technology business units belong to business of question marks. Furthermore, the businesses are strongly supported by the government's policy to develop "pure land industry", ensuring a high market growth rate. As the company has just entered the strange industry for a short time, it is insufficient in marketing and there are problems in product positioning. Its anti-hypoxia drinks are not accepted by tourists, who are the groups suffering altitude sickness, so that products are unsalable and it generates only a small amount of cash. In view of the current development of the enterprise, the question marks have very good prospects for development. Enterprises are advised to invest in human, material and capital, so as to expand their relative market share and convert them into star businesses. For dogs, trade, packaging, tourism and other business units belong to dogs. The enterprise initially thinks these industries are flourishing, so they blindly started to invest in crossindustrial projects. Due to the entry into strange industries, it is unlinked with the original business, and it has no management experience in these industries, so that these business units have low profit margin and are in the state of breaking even or loss and high debt ratio, failing to bring benefits to the enterprise. 


\section{Suggestions on the implementation of investment diversification strategy for A Company}

Diversification operation, especially non-related diversification, is faced with many risks. A Company's non-related diversification strategy faces four risks as follows. First, it is the risk of the original industry. Generally speaking, the enterprise resources are limited, and then the implementation of investment diversification strategy is to disperse the funds of cash cows and to provide cash support for other business units, which means that the original real estate industry has to be weakened. After a long period of time to appropriate the funds of the original industry into the new industry, the enterprise may fall into financial difficulties at the later stage. Although it is reasonable to apply the idle funds of the original industry to invest in new business, the enterprise should set an extent to minimize the risk of the original industry. Second, it is the risk of industry entry. Industry entry is not a simple investment process. After entering a new industry, the enterprise must continuously inject follow-up resources, and the competitive situation of the industry is constantly changing. Third, it is the risk of integrating internal operations. The newly invested industry will have a comprehensive impact on business operations through financial flows, information flows, decisionmaking flows and personnel flows. Different businesses have different requirements for the management mechanism of enterprises. When carrying out the overall strategy design, the enterprise executives must consider the problems of management mechanisms, market models and related business models in different industries. To avoid the conflict between different business units in diversification operation and limited resources, the enterprise should consider in advance how to avoid the risk of integrating internal operations when considering diversification strategies. Fourth, it is the management risk, which is the risk due to the imperfect process management, personnel management and technical management. Management risk is a broad concept, while the overall aspect is management risk of enterprise strategy. To be specific, it includes the risk of human resource management, financial management, operating management and project management. Therefore, the enterprise should take precautions against the management risk in the implementation of the investment diversification strategy, which will play a key role in the success of the strategy. If it isn't comprehensive in precautions in the earlier stage, it will have a major impact on the implementation of the entire strategy in case there is management risk in the later stage.

As the main business is the basis for the development of enterprises and the main source of profit, enterprises should ensure that the main business units continue to create profits in the implementation of non-related diversification, so that it can ensure adequate funding when entering new areas. A Company should closely focus on the development of its main business, so that it will be prone to succeeding. The company executers should make clear strategic management is not to simply choose and implement, but to control the implementation process after the analysis, planning, selection and implementation, in accordance with the changes in internal and external environment and organizational goals. Therefore, in the process of implementing the investment diversification strategy, enterprises should determine the evaluation criteria in the early stage, evaluate the investment results in the middle stage and give feedback in the later stage, so as to achieve the strategic objectives of enterprises. After a period of non-related diversification strategy, enterprises should give feedback and summarize the early implementation of the strategy. Even if the enterprise has good strategic planning and implementation, the market environment is changing rapidly. Changes in the external environment and market conditions will affect the strategic progress of the enterprise. Therefore, after analyzing all the strategic business units of an enterprise through the BCG matrix method, we can conclude which businesses to liquidate and abandon and which businesses to focus on, which will not only save the manpower, material and financial resources of enterprises, but also enable enterprises to get good opportunities for development and gain competitive advantages.

\section{Conclusion}

With the rapid development of society and economy, it is not enough for any enterprise to seek a better development only in the original field of investment. Therefore, as investment diversification 
strategy is a major strategy of enterprise development, in order to avoid the risk of diversified investment for enterprises, but also to enable the enterprise to obtain the most rapid development, we can assist the enterprise in finding out the existing problems in investment through BCG analysis, to create more economic benefits to the enterprise, and to make contributions to economic construction and social development.

\section{References}

[1] Wang Shouguan, Li Lixia, Zhou Rong. Analysis of Non-related Diversification Strategy in W Company in Tibet—Based on BCG Matrix Method [J]. Undertaking \& Investment, 2017 (06): 49-51.

[2] Mi Dongfeng. Research on Development Strategy of Qingyang Real Estate Company [J]. Journal of Shanxi Institute of Economic Management, 2014(04):32- 62.

[3] Yang Yang. Research on Product Selection of HT Paper Based on BCG Matrix [D]. Yanbian University, 2015.

[4] Zhou Zhishuai. Research on Optimization of Diversification Development Strategy of Gansu Innovation Group [J]. Lanzhou University of Technology, 2016.

[5] Cai Bixia, Yan Tao. Reflections on Non-related Diversification Strategy-Take Shenzhen Giant Group as an Example [J]. Business Economy, 2011 (07): 59-60. 